Zbornik Instituta za kriminološka

i sociološka istraživanja

2021 / Vol. XL / 1 / 9-24

Originalni naučni rad

Primljeno: 5. aprila 2021. godine

Prihvaćeno: 13. aprila 2021. godine

DOI: $10.47152 /$ ziksi2021011

UDK: 343.232:656.136.084(497.11)

340.142:656.136.084(497.11

\title{
PRIVREDNI PRESTUPI IZ OBLASTI BEZBEDNOSTI SAOBRAĆAJA NA PUTEVIMA U PRAKSI PRIVREDNOG SUDA U VALJEVU
}

\author{
Dragan Obradović ${ }^{*}$ \\ Stevan Karać*
}

\begin{abstract}
Osim krivičnih dela i prekršaja, u oblasti bezbednosti saobraćaja na putevima postoje i privredni prestupi, specifična vrsta kaznenih dela. $U$ radu smo ukazali na pojedine karakteristike privrednih prestupa i na određene probleme u njihovoj primeni danas. Akcenat smo usmerili na prevoz tereta $s$ obzirom na značaj istog za privredno poslovanje, kao $i$ na privredne prestupe $s$ tim $u$ vezi. Predstavili smo određene podatke od značaja za ovu problematiku u Srbiji i za područje Privrednog suda u Valjevu. Cilj nam je da se kroz probleme koje smo prepoznali i na koje smo ukazali harmonizuje rad policije odnosno pravosuđa na području na kome se prostire nadležnost Privrednog suda u Valjevu i u Srbiji. To je neophodno u cilju efikasnijeg postupanja svih nadležnih državnih organa $u$ ovoj specifičnoj oblasti borbe protiv neodgovornih pravnih lica i odgovornih lica u pravnim licima koja organizuju rad na prevozu tereta u okviru poslova kojima se bave.
\end{abstract}

KLJUČNE REČI: kaznena dela / privredni prestupi / bezbednost saobraćaja na putevima / prevoz tereta

\footnotetext{
* Sudija, Viši sud u Valjevu, Republika Srbija, naučni saradnik. E-mail: dr.gaga.obrad@gmail.com

* Viši sudijski saradnik, Privredni sud u Valjevu, Valjevo, Republika Srbija. E-mail: stevankarac@gmail.com
} 


\author{
Zbornik IKSI, 1/2021 - D. Obradović, S. Karać \\ „Privredni prestupi iz oblasti bezbednosti saobraćaja na putevima u praksi \\ Privrednog suda u Valjevu", (str. 9-24)
}

\begin{abstract}
UVOD
Zaštitna funkcija kaznenog prava, kao dela pozitivnog prava jedne države, ostvaruje se propisivanjem određenih društveno nepoželjnih ponašanja kao kaznenih dela, propisivanjem sankcija za ta dela i u krajnjem procesuiranjem učinilaca takvih dela u zakonom propisanom postupku. Pozitivno pravo Republike Srbije poznaje tri vrste kaznenih dela: krivična dela, prekršaji i privredni prestupi. Kod većeg dela naše laičke, ali i stručne javnosti, kao glavni mehanizmi u borbi za zaštitu i očuvanje najznačajnijih društvenih vrednosti primat imaju krivičnopravno i prekršajno zakonodavstvo, dok su privredni prestupi nekako marginalizovani.
\end{abstract}

Ova grupa kaznenih dela uvedena je u našu pravnu regulativu davne 1977. godine, u vreme specifičnih društveno-političkih, ali i ekonomsko-privrednih okolnosti. Privredni prestupi su nastali u tom vremenu radi zaštite zakonitosti u oblasti privrednog i finansijskog poslovanja. U našem pozitivnom pravu, uz mnogobrojne, ali suštinski relativno zanemarljive izmene, o(p)stali su uprkos opštepoznatim promenama i teškoćama kroz koje su u proteklih tridesetak godina prošli kako naša država, tako i društvo u celini. Ta posebnost ujedno predstavlja i najveću prepreku za pravilno i efikasno pokretanje i sprovođenje postupaka za privredne prestupe u današnjim, bitno izmenjenim prilikama.

Bilo kako bilo, privredni prestupi egzistiraju u našem pravnom sistemu i upravo zbog svoje pozitivnopravne prirode, ne sme se zanemarivati njihov značaj. Osnovni propis u ovoj oblasti jeste Zakon o privrednim prestupima (dalje:Zakon). ${ }^{.}$Zakonom, privredni prestup je definisan kao društveno štetna povreda propisa o privrednom ili finansijskom poslovanju koja je prouzrokovala ili je mogla prouzrokovati teže posledice i koja je propisom nadležnog organa određena kao privredni prestup, s tim što nije privredni prestup ona povreda propisa o privrednom ili finansijskom poslovanju koja, iako sadrži obeležja privrednog prestupa određena propisom, predstavlja neznatnu društvenu štetnost zbog malog značaja i zbog neznatnosti ili odsutnosti štetnih posledica. Inicijalna namera zakonodavca je bila da ograniči njihov domašaj na oblast privrednog i finansijskog poslovanja, ali je u praksi polje njihove primene dosta šire, prostire se i na mnoge druge oblasti, pa i na oblast bezbednosti saobraćaja na putevima.

Cilj nam je da u radu ograničenog obima ukažemo na jedan aspekt kršenja odredaba Zakona o bezbednosti saobraćaja na putevima (dalje: ZBS) ${ }^{2}$ - prevoz tereta u drumskom saobraćaju. O tome se više razmišlja kod saobraćajnih nezgoda, mada

\footnotetext{
${ }^{1}$ Zakon o privrednim prestupima, Službeni list SFRJ, br. 4/77, 36/77, 14/85, 74/87, 57/89, 3/90, Službeni list SRJ br. 27/92, 24/94, 28/96, 64/2001, Službeni glasnik RS, br. 101/2005

${ }^{2}$ Zakon o bezbednosti saobraćaja na putevima, Službeni glasnik RS, br. 41/2009, 53/2010, 101/2011, 32/2013 (Odluka Ustavnog suda), 55/2014, 96/2015, 9/2016 (Odluka Ustavnog suda), 24/2018, 41/2018 (drugi zakon), 41/2018, 87/2018, 23/2019.
} 


\author{
Zbornik IKSI, 1/2021 - D. Obradović, S. Karać \\ „Privredni prestupi iz oblasti bezbednosti saobraćaja na putevima u praksi \\ Privrednog suda u Valjevu", (str. 9-24)
}

značaj pravilnog sagledavanja opterećenosti vozila koja su učestvovala u saobraćajnoj nezgodi prilikom vršenja uviđaja od strane službenih lica nije dovoljno prepoznat (Obradović, 2012:92). Kod saobraćajnih nezgoda u kojima je učestvovalo teretno vozilo, prema podacima iz saobraćajne dozvole i iz otpremnice treba ustanoviti maksimalnu nosivost i opterećenost vozila, a u slučaju sumnje da je teretno vozilo pretovareno, ono može biti upućeno na merenje (Obradović i dr., 2018). Zbog pojedinih propusta u pogledu poštovanja važećih propisa kada je u pitanju prevoz tereta privrednici dolaze u sudske postupke pred nadležne privredne sudove, koji prema pravnim licima i odgovornim licima u pravnim licima dalje primenjuju odredbe Zakona. Predstavili smo relevantne podatke u vezi sa ovim privrednim prestupima u Srbiji. Posebnu pažnju posvetili smo postupanju Privrednog suda u Valjevu u vezi sa ovim predmetima.

\title{
1. POJEDINE KARAKTERISTIKE PRIVREDNIH PRESTUPA
}

Neke od najvažnijih karakteristika su: za privredni prestup može biti odgovorno samo pravno lice i odgovorno lice u pravnom licu, za privredni prestup propisana je samo novčana kazna, ali sud može izreći i uslovnu osudu, kao i zaštitne mere. Za zastarelost gonjenja propisan je rok od tri godine od dana izvršenja privrednog prestupa. ${ }^{3} \mathrm{Na}$ tok i prekid zastarevanja gonjenja, zastarevanje izvršenja kazne ili zaštitnih mera, kao i za apsolutnu zastarelost, shodno se primenjuju odredbe krivičnog zakonodavstva. U funkcionalnom smislu, za suđenje u postupcima za privredne prestupe u prvom stepenu nadležno je veće od jednog sudije - predsednika veća i dvoje sudija-porotnika, 4 dok za privredne prestupe za koje propisana novčana kazna za pravno lice ne prelazi iznos od 100.000 dinara u prvostepenom sudu sudi sudija pojedinac. U drugom stepenu sudovi sude u veću od dvojice sudija, od kojih je jedan predsednik veća i jednog sudije-porotnika. Osobenost privrednih prestupa u odnosu na krivična dela i prekršaje, jeste i da je mesno nadležan sud na čijem se području nalazi sedište okrivljenog pravnog lica, a ne sud na čijem području je privredni prestup učinjen ili pokušan. Optužni akt je isključivo optužni predlog. Osim redovnog postupka zakonodavac je predvideo i skraćeni postupak za koji je nadležan sudija pojedinac, kao i posebne postupke - postupak za oduzimanje imovinske koristi, postupak za naknadu štete zbog neopravdane osude i postupak za brisanje osude, za prestanak zaštitne mere ili pravne posledice osude.

Bez obzira na sličnosti sa krivičnim i prekršajnim postupkom, ovaj postupak ima ozbiljne manjkavosti i nedostatke. Pre svega, Zakon obiluje prevaziđenim, napuštenim i retrogradnim pojmovima kao što su: organi samoupravne radničke

\footnotetext{
3 Osim za privredne prestupe u oblasti spoljnotrgovinskog, deviznog i carinskog poslovanja zastarelost gonjenja nastupa kad protekne pet godina od dana izvršenja privrednog prestupa.

${ }_{4}$ Zakonska odredba iz člana 59. stav 1. navodi "dvojicu sudija-porotnika". Ipak, mišljenja smo da namera zakonodavca nije bila da funkciju sudija porotnika obavljaju samo pripadnici muškog pola, već da je reč o anahronoj jezičkoj konstrukciji, što u ostalom proizlazi i iz svakodnevne prakse u kojoj su i žene ravnopravno članice porote.
} 


\section{Zbormik IKSI, 1/2021 - D. Obradović, S. Karać \\ „Privredni prestupi iz oblasti bezbednosti saobraćaja na putevima u praksi \\ Privrednog suda u Valjevu", (str. 9-24)}

kontrole, zakoni federacije, teritorija Socijalističke Federativne Republike Jugoslavije, savezni sud i drugi... Ovakva terminologija predstavlja relikt davnih vremena, pa ipak čini manji deo problema vezanih za materiju privrednih prestupa. Naime, ovakva zakonska anomalija bi se i mogla prihvatiti kao jezikoslovni problem, 5 no pravi izazov predstavlja okolnost da je ovaj Zakon u velikoj meri do danas oslonjen na krivičnopravnu regulativu. To ne bi bilo sporno, da Zakon ne upućuje na shodnu primenu propisa koji odavno nisu na snazi: Krivičnog zakona Socijalističke Federativne Republike Jugoslavije (dalje: KZ SFRJ) ${ }^{6}$ i Zakona o krivičnom postupku (dalje: ZKP)7.

Prema Zakonu istražne radnje preduzima sud, odnosno određeni sudija. Ovakvo rešenje je razumljivo jer je u vreme donošenja Zakona, pa do 1. oktobra 2013. godine u krivičnom postupku u Srbiji bila dominantna uloga istražnog sudije. Međutim, ovakav model je u našem krivičnom zakonodavstvu napušten sa novim Zakonikom o krivičnom postupku (dalje: Zakonik) ${ }^{8}$, uvođenjem tužilačke istrage. Kako se radi o izuzetno važnoj fazi postupka koja je ključna za obezbeđivanje dokazne građe protiv okrivljenih, očigledne su teškoće sa kojima se susreću svi učesnici u privrednokaznenom postupku.

Prethodno navedeni zakonski nedostaci neminovno iziskuju primenu analogije, a izlišno je govoriti o opasnostima od primene takve metode tumačenja u kaznenom postupku. Cilj rada nije detaljna analiza pravne prirode privrednih prestupa, ni nedostataka ovog Zakona. Ukazali smo samo na najznačajnije nedostatke, po našem mišljenju.

\section{PREVOZ TERETA - JEDAN OD PRIVREDNIH PRESTUPA U PRAKSI}

U kaznenim odredbama ZBS u XXI glavi predviđa pod tačkom 6. privredne prestupe, pa je u članu 325. stav 1 . propisano da će se pravno lice kazniti novčanom kaznom u iznosu od 300.000 do 2.500 .000 dinara za 23 privredna prestupa. Stavom 2. tog člana propisano je da će se za privredni prestup iz stava 1. tog člana kazniti novčanom kaznom od 20.000 do 200.000 dinara odgovorno lice u pravnom licu.

\footnotetext{
${ }^{5} \mathrm{~S}$ obzirom da postoje i drugi zakoni sa sličnim anomalijama koji se uspešno primenjuju dugi niz godina, kao što su Zakon o obligacionim odnosima, Zakon o osnovama svojinskopravnih odnosa, Zakon o menici i drugi.

${ }^{6}$ Krivični zakon Socijalističke Federativne Republike Jugoslavije, Službeni list SFRJ, br. 44/76, 36/77, 34/84, 37/84, 74/87, 57/89, 3/90, 38/90, 45/90, 54/90, Osnovni krivični zakon, Službeni list SRJ, br. 35/92, 16/93, 31/93, 37/93, 24/94, 61/2001, Službeni glasnik RS, br. 39/2003 - primenjivao se od 1.1.1977. do 1.1.2006.godine kada je prestao da važi na osnovu Službeni glasnik RS, br. 85/2005

7 Zakon o krivičnom postupku, Službeni list SFRJ, br. 4/77, 36/77, 14/85, 26/86, 74/87, 57/89, 3/90, Službeni list SRJ, br. 27/92, 24/94, 21/99, 71/oo, 13/2001 i 70/01 od 28.12.2001 - prestaje da važi tri meseca od dana objavljivanja.

8 Zakonik o krivičnom postupku, Službeni.glasnik RS br. 72/2011, 101/2011, 121/2012, 32/2013, 45/2013, 55/2014, 35/2019
} 


\section{Zbormik IKSI, 1/2021 - D. Obradović, S. Karać \\ „Privredni prestupi iz oblasti bezbednosti saobraćaja na putevima u praksi \\ Privrednog suda u Valjevu", (str. 9-24)}

Pažnju smo ograničili samo na jedan od tih privrednih prestupa koje učine pravno lice odnosno odgovorno lice u pravnom licu, od značaja za privredno poslovanje pravnih lica - prevoz tereta i kršenje tog propisa, i to samo na pojedine oblike tog privrednog prestupa. Ključni propis zbog koga smo usmerili pažnju na ovaj privredni prestup je Zakon o prevozu tereta u drumskom saobraćaju, ${ }^{9} \mathrm{~s}$ obzirom na značaj ove problematike za celokupnu privredu Srbije, ali i za druge države jer se preko naše države obavlja i međunarodni tranzit vozila $\mathrm{u}$ putničkom kao i $\mathrm{u}$ teretnom saobraćaju. Odredbe ZBS koje se odnose na prevoz tereta na vozilu primenjuju se na sva teretna vozila koja se zateknu na teritoriji Republike Srbije. U sudskoj praksi u Republici Srbiji to je jedan od najčešćih privrednih prestupa iz ove oblasti.

Tako, ZBS prema važećoj definiciji na snazi od 02.04.2018. godine ${ }^{10}$ propisuje kao privredni prestup postupanje suprotno odredbama iz čl. 112. st. 1. tač. 2) ZBS, kada je premašeno osovinsko opterećenje propisano tehničkim normativima za vozila ili najveća dozvoljena ukupna masa, za više od 5,0\% i tačke 3) ovog stava. Članom 112. ZBS regulisan je prevoz tereta na vozilu, a stavom 1. tog člana propisano je da $\mathrm{u}$ saobraćaju na putu vozilo ne sme da se optereti preko osovinskog opterećenja propisanog tehničkim normativima za vozila i najveće dozvoljene ukupne mase (tač. 2), odnosno tako da vozilo sa teretom premašuje najveće dozvoljene dimenzije za pojedine vrste vozila (dužina, širina i visina) - tač. 3. Zakonodavac je predvideo i osnov isključenja postojanja privrednog prestupa, pa je tako čl.112. st.2. propisano da izuzetno od odredbi st. 1. tač. 2) i 3) tog člana, vozilo, odnosno skup vozila, sme da učestvuje u saobraćaju na putu, uz posebnu dozvolu nadležnog organa. Pobrojani stručni pojmovi navedeni u ovom članu definisani su u čl. 7. ZBS, i to: najueća dozvoljena masa vozila (tač. 59); najveća dozvoljena ukupna masa vozila, odnosno skupa vozila (tač. 60 i 61); osovinsko opterećenje (tač. 64); a najveće dozvoljeno osovinsko opterećenje proizvođača vozila (tač. 64a).

Citiranim propisom kojim je određen pomenuti privredni prestup pored odgovornosti pravnog lica odnosno odgovornog lica predviđena je i odgovornost fizičkog lica - vozača teretnog vozila koji upravlja takvim preopterećnim vozilom odnosno skupom vozila odnosno skupom vozila - novčana kazna u iznosu od 20.000 - 40.00o dinara ili kazna zatvora za tako učinjen prekršaj. Osim toga, vozaču vozila koje sa teretom premašuje najveće dozvoljene dimenzije za pojedine vrste vozila (dužina, širina i visina) - iz čl.112 st.1.tač.3 ZBS sleduje i kumulativno izricanje zaštitne mere zabrana upravljanja motornim vozilom $\mathrm{u}$ trajanju od najmanje 3 meseca kao i 4 kaznena poena.

Može se zaključiti da je radnja izvršenja ovog privrednog prestupa određena dvojako i to:

- prvi oblik sastoji se iz opterećenja vozila koje rezultira premašivanjem osovinskog opterećenja propisanog tehničkim normativima za vozila ili najveće dozvoljene

9 Zakon o prevozu tereta u drumskom saobraćaju, Službeni glasnik RS br. 68/2015, 41/2018

10 Zakon o izmenama i dopunama Zakona o bezbednosti saobraćaja na putevima, Službeni glasnik RS, br. 24/2018, čl.325 st.1.tač.2. 


\author{
Zbornik IKSI, 1/2021 - D. Obradović, S. Karać \\ „Privredni prestupi iz oblasti bezbednosti saobraćaja na putevima u praksi \\ Privrednog suda u Valjevu", (str. 9-24)
}

ukupne mase, za više od 5,0\%. U ovom slučaju radnja je određena alternativno, tj. dovoljno je da se premaši ili osovinsko opterećenje ili najveća dozvoljena ukupna masa vozila kako bi se ostvarilo biće ovog privrednog prestupa. Pritom, nije kažnjivo svako preopterećivanje vozila u pogledu osovinskog opterećenja ili najveće dozvoljene ukupne mase vozila, već samo ono koje prelazi dozvoljenu toleranciju od 5,0\%;

- drugi oblik sastoji se iz opterećenja vozila koje alternativno rezultira premašivanjem najveće dozvoljene dimenzije za pojedine vrste vozila: dužine, širine i visine, pri čemu je kažnjivo premašivanje bilo koje od navedenih dimenzija. Za razliku od prvog oblika, nije predviđena dozvoljena tolerancija, pa je kažnjivo svako premašivanje dimenzija.

Pre tih izmena, privredni prestup u vezi sa prevozom tereta propisan u osnovnom tekstu ZBS ${ }^{11}$ glasio je: "Novčanom kaznom u iznosu od 300.000 do 2.500.000 dinara kazniće se za privredni prestup pravno lice koje postupi suprotno odredbama iz člana 112. stav 1. tačka 2), kada je premašeno osovinsko opterećenje propisano tehničkim normativima za vozila i najveću dozvoljenu ukupnu masu, za više od 5,0\% i tačka 3)". Osim ovih privrednih prestupa u vezi sa prevozom tereta postoje i drugi privredni prestupi, na koje ukazuju pojedini autori (Vujanić i dr., 2009).

Osim razlike u numeraciji (po "starom" je privredni prestup bio propisan članom 325. stavom 1. tačkom 3., a po "novom" članom 325. stavom 1. tačkom 2.), suštinska razlika sastoji se u tome što je za prvi oblik ovog privrednog prestupa pre izmene ZBS, bilo obavezno kumulativno ispunjenje oba propisana uslova - prekoračenje ukupne dozvoljene mase vozila i prekoračenje osovinskog opterećenja za više od $5,0 \%$, dok je po važećem tekstu za postojanje prvog oblika ovog privrednog prestupa dovoljno alternativno ispunjenje jednog od tih uslova. U svemu ostalom, odredba koja se odnosi na pomenuti privredni prestup je ostala bez promena kao i odredba koja se odnosi na prevoz tereta na vozilu. Značaj spomenute izmene je u tome što je povodom prvog oblika napušten kumulativni koncept u pogledu radnje izvršenja ovog privrednog prestupa i prihvaćen alternativni koncept, čime je došlo do pooštravanja zakonskog režima.

Ova okolnost je značajna i zbog postupaka pred Privrednim sudom u Valjevu u periodu od 01.01.2015. godine do 31.12.2019. godine gde je velika većina postupaka povodom ovog privrednog prestupa vođena, pre izmena ZBS.

\footnotetext{
${ }^{11}$ Zakon o bezbednosti saobraćaja na putevima, Službeni glasnik RS, br. 41/2009., čl.325.st.1.tač.3
} 


\author{
Zbornik IKSI, 1/2021 - D. Obradović, S. Karać \\ „Privredni prestupi iz oblasti bezbednosti saobraćaja na putevima u praksi \\ Privrednog suda u Valjevu", (str. 9-24)
}

\title{
3. UKRATKO O PRIVREDNOM SUDU U VALJEVU
}

Privredni sud u Valjevu je shodno Zakonu o uređenju sudova ${ }^{12}$ osnovan za teritoriju više gradova odnosno opština. Nadležan je za teritorije jedanaest opština i tri grada i to opština Bogatić, Vladimirci, Koceljeva, Krupanj, Lajkovac, Ljig, Ljubovija, Mali Zvornik, Mionica, Osečina i Ub i gradova Valjevo, Loznica i Šabac. Postoji i sudska jedinica u Loznici za teritoriju opština Krupanj, Ljubovija i Mali Zvornik i za grad Loznicu i sudska jedinica u Šapcu za teritoriju opština Bogatić, Vladimirci i Koceljeva i za grad Šabac ${ }^{13}$.

Kako se u privrednoprestupnom pravu mesna nadležnost suda određuje na osnovu sedišta okrivljenog pravnog lica $u$ trenutku izvršenja privrednog prestupa, to je Privredni sud u Valjevu nadležan da u prvom stepenu odlučuje o privrednim prestupima izvršenim ili pokušanim od strane pravnih lica koja imaju sedište na području pobrojanih gradova i opština.

\section{PRIVREDNI PRESTUPI IZ BEZBEDNOSTI SAOBRAĆAJA U SRBIJI I PRIVREDNOM SUDU U VALJEVU}

Da bismo mogli na adekvatan način sagledati privredne prestupe $\mathrm{u}$ postupcima $\mathrm{u}$ Privrednom sudu u Valjevu analizirali smo samo jedan, po našem mišljenju najznačajniji aspekt i za teritoriju Republike Srbije, a to su primljeni privredni prestupi u radu svih sudova u istom periodu kako će biti analizirano, samo detaljnije za područje Privrednog suda u Valjevu.

Tabela 1: Primljeni privredni prestupi u Srbiji

\begin{tabular}{c|c|c|c|c|c|c|c}
\multirow{4}{*}{ Ukupno } & Godina & 2015 & 2016 & 2017 & 2018 & 2019 & ukupno \\
\cline { 2 - 8 } & Svi predmeti & 1013 & 5726 & 6196 & 9194 & 7764 & 29893 \\
\cline { 2 - 8 } & Zakon o računovodstvu & 275 & 5266 & 5669 & 8828 & 7345 & 27383 \\
\cline { 2 - 8 } & ZBS & $\mathbf{9 4}$ & $\mathbf{8 0}$ & $\mathbf{8 3}$ & $\mathbf{2 8}$ & $\mathbf{2 6}$ & $\mathbf{3 1 1}$
\end{tabular}

U prvoj tabeli na osnovu podataka Republičkog zavoda za statistiku za period 2015 2019. godine ${ }^{14}$ prikazani su osnovni statistički parametri u vezi sa privrednim

\footnotetext{
12 Zakon o uređenju sudova, Službeni glasnik RS br. 116/2008, 104/2009, 101/2010, 31/2011, 78/2011 (drugi zakon), 101/2011, 101/2013, 40/2015 (drugi zakon), 106/2015, 13/2016, 108/2016, 113/2017, 65/2018 (Odluka Ustavnog suda), 87/2018, 88/2018 (Odluka Ustavnog suda), čl. 14. st. 2 13 Zakon o sedištima i područjima sudova i javnih tužilaštava, Službeni glasnik RS, br. 101/2013). čl. 5. st. 1. tač. 2

14 Republički zavod za statistiku, Bilten 619, Pravna i odgovorna lica - učinioci privrednih prestupa u Republici Srbiji, 2015, Beograd 2016.; Republički zavod za statistiku, Bilten 631, Pravna i odgovorna lica učinioci privrednih prestupa u Republici Srbiji, 2016, Beograd 2017.; Republički zavod za statistiku, Bilten 642, Pravna i odgovorna lica - učinioci privrednih prestupa u Republici Srbiji, 2017, Beograd 2018.; Republički zavod za statistiku, Bilten 655, Pravna i odgovorna lica - učinioci privrednih prestupa u
} 


\section{Zbormik IKSI, 1/2021 - D. Obradović, S. Karać \\ „Privredni prestupi iz oblasti bezbednosti saobraćaja na putevima u praksi \\ Privrednog suda u Valjevu", (str. 9-24)}

prestupima: broj svih primljenih predmeta po godinama, ukupan broj najzastupljenijih privrednih prestupa u praksi privrednih sudova i ukupan broj privrednih prestupa protiv bezbednosti saobraćaja. Smatramo da je to relevantan period radi izvođenja određenih, validnih zaključaka.

Iz navedenih podataka uočava se da su u periodu od 01.01.2015. godine do 31.12.2019. godine dominantna grupa u svim privrednim sudovima na teritoriji Republike Srbije bili privredni prestupi u vezi sa Zakonom o računovodstvu. Takođe, uočljivo je da broj privrednih prestupa iz grupe protiv bezbednosti javnog saobraćaja $\mathrm{u}$ istom periodu opada. Iste ove zakonitosti uočene su i u Privrednom sudu u Valjevu što će se videti u narednoj tabeli.

Predmet analize u daljem tekstu bili su predmeti privrednih prestupa primljeni u Privrednom sudu u Valjevu od 01.01.2015. - 31.12.2019. godine na osnovu godišnjih izveštaja o radu suda.

Tabela 2: Primljeni privredni prestupi

\begin{tabular}{c|c|c|c|c|c|c|c}
\multirow{4}{*}{ Ukupno } & Godina & 2015 & 2016 & 2017 & 2018 & 2019 & ukupno \\
\cline { 2 - 8 } & Svi predmeti & 70 & 858 & 518 & 1124 & 644 & 3206 \\
\cline { 2 - 8 } & Zakon o računovodstvu & 16 & 820 & 479 & 1075 & 556 & 2946 \\
\cline { 2 - 9 } & ZBS & $\mathbf{1 6}$ & $\mathbf{1 1}$ & $\mathbf{8}$ & $\mathbf{3}$ & $\mathbf{1}$ & $\mathbf{3 9}$
\end{tabular}

U ovoj tabeli prikazani su osnovni statistički parametri: broj svih primljenih predmeta u periodu od 01.01.2015. do 31.12.2019. godine po godinama, ${ }^{15}$ ukupan broj najzastupljenijih privrednih prestupa i ukupan broj privrednih prestupa protiv bezbednosti saobraćaja. Smatramo da je to relevantan period radi izvođenja određenih, validnih zaključaka.

U posmatranom periodu primljeno je ukupno 39 predmeta u vezi sa privrednim prestupima protiv bezbednosti saobraćaja. Očigledna je tendencija pada broja ovih predmeta kao i Srbiji. A tokom 2020. godine nije bio u radu nijedan predmet iz ove oblasti.

U daljem tekstu analizirali smo različite parametre koji se odnose na privredne prestupe iz grupe protiv bezbednosti saobraćaja u radu Privrednog suda u Valjevu u istom periodu.

Republici Srbiji, 2018, Beograd 2019; Republički zavod za statistiku, Bilten 667, Pravna i odgovorna lica učinioci privrednih prestupa u Republici Srbiji, 2019, Beograd 2020.

${ }_{15}$ Predmeti su svrstavani po kalendarskim godinama na osnovu trenutka prijema optužnog predloga u sud. 


\begin{abstract}
Zbornik IKSI, 1/2021 - D. Obradović, S. Karać
„Privredni prestupi iz oblasti bezbednosti saobraćaja na putevima u praksi

Privrednog suda u Valjevu", (str. 9-24)
\end{abstract}

Tabela 3: Vrste pravnosnažnih odluka po privrednim prestupima

\begin{tabular}{|c|c|c|c|c|c|c|c|c|}
\hline \multirow{8}{*}{$\begin{array}{l}\text { Vrsta } \\
\text { odluke }\end{array}$} & \multirow{5}{*}{ Presude } & Godina & 2015 & 2016 & 2017 & 2018 & 2019 & Ukupno \\
\hline & & osuđujuće & 11 & 3 & 2 & 2 & I & 18 \\
\hline & & oslobađajuće & I & l & I & 1 & I & I \\
\hline & & odbijajuće & 2 & 1 & 4 & 1 & 1 & 7 \\
\hline & & „mešovite“ & 1 & 2 & 1 & 1 & 1 & 3 \\
\hline & \multirow{3}{*}{ Rešenja } & o obustavi postupka & 1 & 1 & 1 & 1 & 1 & 1 \\
\hline & & o nenadležnosti & 1 & I & 1 & I & I & 2 \\
\hline & & o spajanju postupaka & 1 & 5 & l & 1 & / & 7 \\
\hline
\end{tabular}

Velika većina predmeta u vezi sa privrednim prestupima koji se odnose na kršenje propisa iz ZBS je pravnosnažno okončana - 38 od 39 predmeta. U jednom predmetu, pod poslovnim brojem Pk.br.376/2019 godine doneta je prvostepena osuđujuća presuda protiv koje je izjavljena žalba, predmet se nalazi pred Privrednom apelacionom sudom. Od pravnosnažno završenih predmeta, 28 ih je okončano donošenjem presude: 18 osuđujućih, 3 "mešovite"16 i 7 odbijajućih, a 10 predmeta rešenjem i to: 1 je okončan rešenjem o obustavi postupka, 2 rešenjem o nenadležnosti a 7 rešenjima o spajanju spisima drugih predmeta.

Procenat osuđujućih presuda u odnosu na ukupan broj pravnosnažno okončanih predmeta je 47,36\% (18 od 38). Zajedno sa predmetima koji su završeni rešenjima o spajanju to je nešto preko $58 \%$, a ako u osuđujuće uračunamo i "mešovite" presude, to je $67,74 \%$.

Uvidom u presude uočeno je da se sud prilikom utvrđivanja odgovornosti okrivljenih za privredni prestup vodio pre svega priloženom pismenom dokumentacijom, koja kao dokazna građa postoji u svakom od 18 predmeta okončanih osuđujućom presudom. Pismena dokumentacija se uglavnom sastoji iz sledećih isprava: zapisnika o izvršenoj kontroli Ministarstva unutrašnjih poslova (sa nastavkom zapisnika), zapisnika o merenju osovinskog opterećenja odnosno ukupne mase vozila odnosno skupa vozila JP "Putevi Srbije", potvrda o primeni posebnih mera i ovlašćenja i privremeno oduzetim registarskim tablicama, putnih isprava, stranih vozačkih dozvola u predmetu i izdatom naređenju o isključenju vozača-vozila iz saobraćaja, uverenja o overavanju merila i izvoda iz kaznene evidencije za okrivljene. $\mathrm{Na}$ osnovu njih, sud je utvrđivao relevantne činjenice vezane za opterećenje vozila, a na osnovu izvoda iz kaznene evidencije za okrivljene činjenice od značaja za odmeravanje visine kazne. Dalje, u 8 od 18 postupaka, izvođen je dokaz saslušanja svedoka - različita lica (vozači vozila, policijski službenici koji su vršili kontrolu saobraćaja, radnici JP "Putevi Srbije"). Njihove iskaze sud je različito cenio, u zavisnosti od njihove (ne)usaglašenosti sa prioritetnim pismenim ispravama. Najređe korišćeno dokazno sredstvo bilo je veštačenje posredstvom veštaka saobraćajne struke, koji dokaz je izvođen u samo 4 postupka.

${ }^{16}$ U pitanju su postupci vođeni protiv više okrivljenih pravnih i odgovornih lica, u kojima su presudom jedno pravno i odgovorno lice oglašeni krivim, a prema drugom pravnom i odgovornom licu je optužba odbijena. 


\section{Zbormik IKSI, 1/2021 - D. Obradović, S. Karać \\ „Privredni prestupi iz oblasti bezbednosti saobraćaja na putevima u praksi \\ Privrednog suda u Valjevu", (str. 9-24)}

Tabela 4: Vrste izrečenih sankcija za osuđene

\begin{tabular}{l|l|c|c|c|c|c|c}
\multirow{2}{*}{$\begin{array}{l}\text { Izrečene } \\
\text { sankcije }\end{array}$} & Godina & 2015 & 2016 & 2017 & 2018 & 2019 & Ukupno \\
\cline { 2 - 8 } & Novčane kazne & 10 & 3 & 2 & 1 & $/$ & 16 \\
\cline { 2 - 8 } & Uslovna osuda & 1 & $/$ & $/$ & 1 & $/$ & 2
\end{tabular}

Od 18 osuđujućih presuda, u 16 su izrečene (novčane) kazne, a u 2 presude su izrečene uslovne osude. Visina izrečenih novčanih kazni za okrivljena pravna lica kretala se od 20.000 dinara do 160.000 dinara, dok su odgovorna lica kažnjavana u visini od 4.000 dinara do 14.000 dinara. S obzirom da je za ovaj privredni prestup zaprećena novčana kazna od 300.000 do 2.500.000 dinara za pravna lica i od 20.000 do 200.00o dinara za odgovorno lice u pravnom licu, sud je u svih 16 slučajeva izricanja novčanih kazni primenjivao pravila o ublažavanju i okrivljenima odmeravao kazne ispod najmanje mere propisane za ovaj privredni prestup. Postavlja se pitanje opravdanosti takve prakse suda? Naime, u pitanju je zakonska mogućnost, a ne obaveza. Kazna se može ublažiti kad to predviđa Zakon ili propis kojim je određen privredni prestup, ili ako sud nađe da postoje naročito olakšavajuće okolnosti. Pošto ZBS, kao propis kojim je privredni prestup određen, ne predviđa mogućnost ublažavanja, to je sud ublažavanje kazne po pravilu opravdavao postojanjem naročito olakšavajućih okolnosti kao što su: najčešće ekonomsko stanje i loše poslovanje pravnog lica, raniju neosuđivanost pravnog i odgovornog lica, kao i imovinske i porodične prilike okrivljenog odgovornog lica.

Nelogičnosti u primeni instituta ublažavanja kazne uočene su u presudi Pk.br.27/16 od 04.11.2016. godine prema okr. pravnom licu Strugara "R." DOO iz Č. i okr. odgovornom licu D.R. iz Č., koji su bili prethodno osuđivani za isti privredni prestup (presudom Pk.25/25 od 22.04.2015. godine), gde je sud veći značaj dao porodičnim prilikama okrivljenog - odgovornog lica, činjenici da mesečno zarađuje 22.000 dinara, te da su okrivljeni priznali izvršenje privrednog prestupa, kao naročito olakšavajućim okolnostima, u odnosu na ranije osuđivanosti. Istovetan stav izražen je i u presudi Pk.br.376/19 od 23.05.2019. godine prema istim okrivljenim licima, koja presuda nije pravnosnažna, pa dalji komentar nije celishodan.

U postupku Pk.br.447/17 od 06.06.2019. godine vođenom protiv "D. GROUP" DOO V. kao okr.pravnog lica i okr. A.D. iz M. kao odgovornog lica okrivljeno pravno lice je $\mathrm{u}$ izreci presude označeno kao neosuđivano za privredne prestupe iako je presudom Privrednog suda u Valjevu Pk.br.58/2015 od 24.03.2017. godine pravnosnažno osuđeno. Iz pomenute presude može se zaključiti da izvod iz kaznene evidencije za okrivljene nije bio upotrebljen kao dokaz u postupku zato što je javni tužilac propustio da izvođenje tog dokaza predloži u okviru optužnog akta. Zbog toga, izostalo je izvođenje dokaza od značaja za odmeravanje visine kazne, gde bi sud eventualno doneo drugačiju odluku da je spomenuti dokaz izveden.

Osuđena pravna i odgovorna lica su pretežno oglašavana krivim za oblik privrednog prestupa iz čl. 112. st. 1. tač. 2, u odnosu na tačku 3. istog stava i člana ZBS. Tako, u 15 slučajeva sud je okrivljene oglašavao krivim zbog opterećenja vozila preko osovinskog opterećenja propisanog tehničkim normativima za vozila i najveće dozvoljene ukupne mase, a u 3 slučaja zbog opterećenja vozila tako da ono sa 


\section{Zbormik IKSI, 1/2O21 - D. Obradović, S. Karać \\ „Privredni prestupi iz oblasti bezbednosti saobraćaja na putevima u praksi \\ Privrednog suda u Valjevu", (str. 9-24)}

teretom premašuje najveće dozvoljene dimenzije za pojedine vrste vozila (dužina, širina i visina). Nije primetna drastična razlika u sankcionisanju dva oblika privrednog prestupa, s obzirom da je sud za manje zastupljeni oblik (tačka 3.), izrekao dve novčane kazne u iznosima od 50.000,oo dinara i 150.000,00 dinara za pravna lica, i 10.000,00 dinara i 5.000,00 dinara za odgovorna lica, kao i jednu uslovnu osudu što je sve u okviru opšteg opsega kazni o kojem je već bilo reči.

U dva predmeta okrivljenima su izrečene uslovne osude. U predmetu Pk.br.24/2015 sud se vodio razlozima da je okrivljeno pravno lice u 2014. godini poslovalo pozitivno, porodičnim prilikama okrivljenog odgovornog lica - oženjen, otac dvoje dece, kao i da su okrivljeni neosuđivani. Osim toga, sud je kao opredeljujuću, uzeo u obzir i činjenicu da se u tom slučaju radilo o minimalnom prekoračenju zakonom dozvoljenog osovinskog opterećenja od svega $0,83 \% \mathrm{u}$ odnosu na dozvoljenu toleranciju opterećenja. U predmetu Pk.br.741/18 za sud su bile dovoljne okolnosti vezane za ekonomsku snagu okrivljenog pravnog lica, porodične i imovinske prilike okrivljenog odgovornog lica, kao i ranije neosuđivanost okrivljenih, pa da im umesto kazne izrekne uslovnu osudu, uprkos činjenici da su okrivljeni, osim za predmetni privredni prestup, oglašeni krivim i za privredni prestup iz člana 110.st.1.tač.11. i st.2. Zakona o putevima. U oba slučaja izricanja uslovne osude, sud je u obrazloženju presuda navodio da će se izrečenim uslovnim osudama postići cilj i svrha kažnjavanja. Imajući u vidu da uslovna osuda po svojoj prirodi predstavlja meru upozorenja, a ne kaznu, spornu formulaciju bi ubuduće trebalo izostavljati, jer se svrha kažnjavanja može postići isključivo kaznom, a ne i merom upozorenja.

Za razliku od krivičnog postupka, primetno je da u postupcima za privredne prestupe okrivljeni u značajno manjoj meri angažuju branioce iz reda advokata.

Tabela 5: Učešće branioca u postupcima za privredne prestupe

\begin{tabular}{c|c|c|c|c|c|c} 
Godina & 2015 & 2016 & 2017 & 2018 & 2019 & Ukupno \\
\hline Branioci u predmetu & 7 & 2 & 3 & $/$ & $/$ & 12
\end{tabular}

Od 18 postupaka koji su pravnosnažno završeni osuđujućim presudama, u 7 su okrivljene kao branioci zastupali advokati. Za sve predmete zajedničko je da je oba okrivljena (pravno lice i odgovorno lice u pravnom licu) zastupao jedan branilac.

Vrlo značajna faza svakog sudskog postupka jeste i drugostepeni postupak.

Tabela 6: Odluke po žalbi

\begin{tabular}{|c|c|c|c|c|c|c|c|}
\hline \multicolumn{2}{|c|}{ Godina } & 2015 & 2016 & 2017 & 2018 & 2019 & Ukupno \\
\hline \multicolumn{2}{|c|}{$\begin{array}{l}\text { Ukupan broj izjavljenih žalbi protiv } \\
\text { prvostepenih presuda }\end{array}$} & 4 & 2 & 1 & / & / & 1 \\
\hline \multirow{2}{*}{ Ishod žalbi } & usvojene & 1 & 1 & 1 & 1 & 1 & 1 \\
\hline & odbijene & 4 & 1 & 1 & / & / & 6 \\
\hline
\end{tabular}

Od 18 postupaka završenih osuđujućim presudama, u 6 su izjavljene žalbe protiv prvostepene presude od strane okrivljenih i putem branilaca - advokata. U svih 6 slučajeva, drugostepeni sud je odbijao žalbe kao neosnovane. Kao odlučujuće razlog 


\section{Zbornik IKSI, 1/2021 - D. Obradović, S. Karać \\ „Privredni prestupi iz oblasti bezbednosti saobraćaja na putevima u praksi \\ Privrednog suda u Valjevu", (str. 9-24)}

za odbijanje žalbi, drugostepeni sud je isticao da je prvostepeni sud pravilno utvrdio činjenično stanje i na tako utvrđeno činjenično stanje pravilno primenio materijalno pravo, kao i da se tokom postupka i obrazloženje presude, prvostepeni sud u dovoljnoj meri bavio odbranom okrivljenih i istu pravilno ocenio kao neosnovanu. $\mathrm{U}$ jedinom slučaju kada je Privredni apelacioni sud presudom Pkž 336/16 od 27.04.2017. godine preinačio prvostepenu odluku u predmetu Pk.br.13/2016 u drugostepenoj odluci je navedeno da samostalna autoprevoznička radnja nema svojstvo pravnog lica, te da se ne može ni podvrgnuti privredno-kaznenoj odgovornosti.

U posmatranom periodu kada je u pitanju povrat ukupno 4 pravna i odgovorna lica su oglašena krivim za privredne prestupe više od jedanput, ako se uzmu u obzir i „mešovite“ presude. Tako, u 3 slučaja su pravna lica i odgovorna lica osuđivana po dva puta, pri čemu je u odnosu jedno od tih pravnih lica odnosno odgovornih lica doneta i treća osuđujuća presuda koja nije pravnosnažna ${ }^{17}$, dok su u jednom slučaju pravno lice i odgovorno lice tri puta pravnosnažnim presudama osuđivani za iste privredne prestupe.

Od ostalih statističkih parametara, kao relevantne izdvajamo sedišta okrivljenih pravnih lica odnosno prebivališta okrivljenih odgovornih lica.

Tabela 7: Sedišta pravnih lica koja su izvršila privredne prestupe i vrste odluka

\begin{tabular}{l|c|c|c|c|c} 
Sedišta pravnog lica & osuđujuće & odbijajuće & nenadležnost & obustava & Ukupno \\
\hline Loznica & 7 & 6 & & 1 & 14 \\
\hline Valjevo & 8 & 2 & & & 10 \\
\hline Šbac & 3 & 1 & & & 4 \\
\hline Ljig & 1 & & & & 1 \\
\hline Vladimirci & 1 & & & & 1 \\
\hline Ub & 1 & 1 & & & 2 \\
\hline Grad Beograd & & & 2 & & 2 \\
\hline Mali Zvornik & & 1 & & & 1
\end{tabular}

Tabela 8: Prebivalište odgovornog lica u pravnom licu koja su izvršila privredne prestupe i vrste odluka

\begin{tabular}{l|c|c|c|c|c}
\multicolumn{1}{c|}{$\begin{array}{c}\text { Prebivalište } \\
\text { odgovornog lica }\end{array}$} & osuđujuće & odbijajuće & nenadležnost & obustava & Ukupno \\
\hline Loznica & 7 & 6 & & 1 & 14 \\
\hline Valjevo & 6 & 2 & & & 8 \\
\hline Šabac & 2 & 1 & & & 3 \\
\hline Ljig & 1 & & & & 1 \\
\hline Vladimirci & 1 & & & & 1 \\
\hline Ub & 1 & 1 & & & 2 \\
\hline Mionica & 2 & & & & 2 \\
\hline Grad Beograd & 1 & & 2 & & 1
\end{tabular}

${ }_{17}$ Protiv "STRUGARA R." DOO Č. i D.R. iz Č. doneta je i treća osuđujuća presuda, Pk.br.376/19 od 23.05.2019. godine, koja nije pravnosnažna. 


\author{
Zbornik IKSI, 1/2021 - D. Obradović, S. Karać \\ „Privredni prestupi iz oblasti bezbednosti saobraćaja na putevima u praksi \\ Privrednog suda u Valjevu", (str. 9-24)
}

Podaci za osuđena pravna lica pokazuju da su u najvećem broju slučajeva imala sedište na teritoriji gradova Valjeva - 8 slučajeva, Loznica - 7 i Šabac sa 3 slučaja u kojim gradovima su u najvećem broju slučajeva imala i prebivališta okrivljena odgovorna lica koji su osuđeni Loznice - 7 slučajeva, a zatim sledi grad Valjevo sa 6, grad Šabac i opština Mionica sa 2 slučaja. U svim ostalim slučajevima u pitanju su pojedinačni slučajevi sedišta osuđenih pravnih lica odnosno prebivališta okrivljenih odgovornih lica u pravnom licu. Kada je reč o sedištima pravnih lica prema kojima je optužba odbijena, odnosno o prebivalištima odgovornih lica prema kojima je optužba odbijena u 6 slučajeva sedište pravnog lica bilo je na teritoriji grada Loznice, u 2 slučaja na teritoriji grada Valjeva. U svim ostalim slučajevima gde je došlo do odbijanja optužbe u pitanju su pojedinačni slučajevi sedišta osuđenih pravnih lica odnosno prebivališta okrivljenih odgovornih lica u pravnom licu. (Razlika u broju pravnih lica u odnosu na broj postupaka za privredne prestupe je posledica toga što su pojedina pravna lica izvršila privredne prestupe više puta, o čemu je bilo reči).

\title{
ZAKLJUČAK
}

Uprkos marginalizovanom statusu privredni prestupi zavređuju mnogo veću pažnju, jer su prisutni u gotovo svakoj sferi života. Privredne prestupe, osim u tradicionalnim materijalnim izvorima kao što su Zakon o privrednim društvima, Zakon o računovodstvu itd, srećemo i u kaznenim odredbama, mnogih drugih zakona, pored prekršaja, pa i u odredbama Zakon o bezbednosti saobraćaja na putevima. Namera zakonodavca očigledno je bila da privrednim prestupima nameni značajniju ulogu u suzbijanju društveno nepoželjnih ponašanja u odnosu na njihovu zakonsku definiciju.

U radu je analizirana primena postupaka za privrednih prestupa iz oblasti saobraćaja u petogodišnjem periodu pred Privrednim sudom u Valjevu, u kom periodu su iza neprikosnovenog Zakona o računovodstvu, ${ }^{18}$ privredni prestupi iz Zakona o bezbednosti saobraćaja na putevima bili drugi najzastupljeniji, iako je uočljivo je da njihov broj rapidno opada što iznenađuje, imajući u vidu da je od 02.04.2018. godine na snazi oštriji zakonski režim analiziranog privrednog prestupa. Uzroci ovakve negativne tendencije mogu biti različiti (povećana disciplina učesnika u saobraćaju, pozitivni efekti sankcionisanja, ali i nedovoljno efikasan rad policije i drugih nadležnih organa $\mathrm{u}$ suzbijanju privrednih prestupa). Njihovo tačno definisanje zahtevalo bi analizu svih relevantnih faktora u okviru posebnog rada.

Preovlađujući utisak, po našoj oceni, zapravo je izuzetno mali procenat osuđujućih presuda -manje od 50\% (18 od 38). Kao glavni razlog ovakvog stanja vidimo

\footnotetext{
${ }^{18}$ Od 2016. godine, pa zaključno sa 2020.godinom, primetan je drastičan skok broja postupaka pred privrednim sudovima u Srbiji, pa i pred Privrednim sudom u Valjevu povodom Zakona o računovodstvu koji prema podcima iz 2019. godine u Srbiji čine 91,60\% svih primljenih privrednih prestupa, a u Privrednom sudu u Valjevu 91,89\% svih privredno kaznenih postupaka.
} 


\section{Zbormik IKSI, 1/2021 - D. Obradović, S. Karać \\ „Privredni prestupi iz oblasti bezbednosti saobraćaja na putevima u praksi \\ Privrednog suda u Valjevu", (str. 9-24)}

nedovoljno temeljnu pripremu javnih tužilaca pre samog optuženja. Bez obzira na sve pobrojane objektivne nedostatke, Zakon o privrednim prestupima pruža dovoljno dobre mogućnosti javnim tužiocima za kvalitetnu pripremu optužnog akta. Tu su pre svega ovlašćenja javnog tužioca da prikupi potrebna dodatna obaveštenja od pripadnika MUP odnosno nadležnih inspekcija, kao najčešćih podnosilaca prijava, ali i da preduzme druge mere radi otkrivanja učinioca privrednog prestupa i obezbeđenja dokaza. Takođe, ne smeju se zanemariti ni ovim Zakonom propisane istražne radnje. Iako je u krivičnom zakonodavstvu, institucija istražnog sudije napuštena, u Zakonu je takvo rešenje ipak zadržano, zbog čega je i Sudskim poslovnikom predviđen tzv. "Pki" upisnik za prethodni postupak po privrednim prestupima. Dodatni razlog zbog koga smatramo da javni tužioci ne pokazuju neophodan nivo posvećenosti pri postupanju $\mathrm{u}$ ovoj materiji, je $\mathrm{u}$ tome što $\mathrm{u}$ obrađenim predmetima nismo zabeležili nijedan slučaj u kojem su javni tužioci od suda zahtevali sprovođenje istražnih radnji i na taj način dopunu dokazne građe pre podnošenja optužnog predloga.

S obzirom da privredni prestupi predstavljaju značajnu kazneno-pravnu kategoriju jer se radi o kaznenim delima za koja su propisane visoke novčane kazne, potreban je mnogo ozbiljniji pristup svih učesnika u postupku, a pre svega javnih tužilaca pošto svaka procesna greška i nepažnja može rezultirati oslobađajućom presudom odnosno odustankom javnog tužioca od optužbe. Takav epilog nepovoljno utiče na težnje države ka suzbijanju ovih dela, a ne treba zaboraviti ni negativni materijalni aspekt, odnosno udar na budžetska sredstva, imajući u vidu visoke tarife za pružene advokatske usluge okrivljenima u ovim kaznenim postupcima.

\section{LITERATURA}

(1) Obradović, D. (2012) Uviđaj kod saobraćajnih nezgoda i naknada štete. Beograd: Intermex

(2) Obradović, D (2018) Propusti službenih lica prilikom vršenja uviđaja saobraćajne nezgode - Specifičnosti uviđaja u slučaju saobraćajnih nezgoda, u: M.Nešić, D.Obradović (ur.) Uviđaj saobraćajnih nezgoda za javne tužioce i saobraćajnu policiju. Beograd, Pravosudna akademija, IP"Glosarijum“, str.101-122.

(3) Vujanić, M., Lipovac, K., Jovanović, S. Milojević, D. (2009) Komentar Zakona o bezbednosti saobraćaja na putevima. Beograd: Službei glasnik

(4) Republički zavod za statistiku, Bilten 619, Pravna i odgovorna lica - učinioci privrednih prestupa u Republici Srbiji, 2015, Beograd 2016.

(5) Republički zavod za statistiku, Bilten 631, Pravna i odgovorna lica - učinioci privrednih prestupa u Republici Srbiji, 2016, Beograd 2017.

(6) Republički zavod za statistiku, Bilten 642, Pravna i odgovorna lica - učinioci privrednih prestupa u Republici Srbiji, 2017, Beograd 2018.

(7) Republički zavod za statistiku, Bilten 655, Pravna i odgovorna lica - učinioci privrednih prestupa u Republici Srbiji, 2018, Beograd 2019.

(8) Republički zavod za statistiku, Bilten 667, Pravna i odgovorna lica - učinioci privrednih prestupa u Republici Srbiji, 2019, Beograd 2020. 


\author{
Zbornik IKSI, 1/2021 - D. Obradović, S. Karać \\ „Privredni prestupi iz oblasti bezbednosti saobraćaja na putevima u praksi \\ Privrednog suda u Valjevu", (str. 9-24)
}

\title{
Propisi:
}

(9) Krivični zakon Socijalističke Federativne Republike Jugoslavije, Službeni list SFRJ, br. 44/76, 36/77, 34/84, 37/84, 74/87, 57/89, 3/90, 38/90, 45/90, 54/90, Osnovni krivični zakon, Službeni list SRJ, br. 35/92, 16/93, 31/93, 37/93, 24/94, 61/2001, Službeni glasnik RS, br. 39/2003.

(10) Zakon o bezbednosti saobraćaja na putevima, Službeni glasnik RS, br. 41/2009, 53/2010, 101/2011, 32/2013 (Odluka Ustavnog suda), 55/2014, 96/2015, 9/2016 (Odluka Ustavnog suda), 24/2018, 41/2018 (drugi zakon), 41/2018, 87/2018, 23/2019.

(11) Zakon o krivičnom postupku, Službeni list SFRJ, br. 4/77, 36/77, 14/85, 26/86, 74/87, 57/89, 3/90, Službeni list SRJ, br. 27/92, 24/94, 21/99, 71/oo, 13/2001 i 70/01 od 28.12.2001.

(12) Zakonik o krivičnom postupku, Službeni.glasnik RS br. 72/2011, 101/2011, $121 / 2012,32 / 2013,45 / 2013,55 / 2014,35 / 2019$.

(13) Zakon o prevozu tereta u drumskom saobraćaju, Službeni glasnik RS br. 68/2015, 41/2018.

(14) Zakon o privrednim prestupima, Službeni list SFRJ, br. 4/77, 36/77, 14/85, 74/87, 57/89, 3/90, Službeni list SRJ br. 27/92, 24/94, 28/96, 64/2001, Službeni glasnik RS, br. 101/2005.

(15) Zakon o sedištima i područjima sudova i javnih tužilaštava, Službeni glasnik RS, br. 101/2013).

(16) Zakon o uređenju sudova, Službeni glasnik RS br. 116/2008, 104/2009, 101/2010, 31/2011, 78/2011 (drugi zakon), 101/2011, 101/2013, 40/2015 (drugi zakon), 106/2015, 13/2016, 108/2016, 113/2017, 65/2018 (Odluka Ustavnog suda), 87/2018, 88/2018 (Odluka Ustavnog suda).

Sudska praksa:

(17) Presuda Privrednog suda u Valjevu Pk.br.27/16 od 04.11.2016., pravnosnažna, neobjavljena

(18) Presuda Privrednog suda u Valjevu Pk.25/25 od 22.04.2015., pravnosnažna, neobjavljena

(19) Presuda Privrednog suda u Valjevu Pk.br.447/17 od 06.06.2019., pravnosnažna, neobjavljena

(20) Presuda Privrednog suda u Valjevu Pk.br.58/15 od 24.03.2017., pravnosnažna, neobjavljena

(21) Presuda Privrednog suda u Valjevu Pk.br.24/15 od 05.05.2015., pravnosnažna, neobjavljena

(22) Presuda Privrednog suda u Valjevu Pk.br.741/18. od 23.07.2019., pravnosnažna, neobjavljena

(23) Presuda Privrednog suda u Valjevu Pk.br.376/19 od 23.05.2019., nepravnosnažna

(24) Presuda Privrednog suda u Valjevu Pk.br.6/16 od 14.03.2016., pravnosnažna, neobjavljena

(25) Presuda Privrednog suda u Valjevu Pk.br.178/17 od 26.03.2018., pravnosnažna, neobjavljena

(26) Presuda Privrednog suda u Valjevu Pk.br.13/2016 od 14.10.2016. zajedno sa presudom Privrednog apelacionog suda Pkž 336/16 od 27.04.2017., pravnosnažna, neobjavljena 


\section{ECONOMIC OFFENSES IN THE FIELD OF ROAD SAFETY IN THE PRACTICE OF THE COMMERCIAL COURT IN VALJEVO}

In addition to criminal acts and misdemeanors, in the field of road traffic safety, there are also economic offenses, a specific type of criminal offenses. In this paper, we have pointed out certain characteristics of economic crimes and certain problems in their application today. We focused on the transport of cargo, given its importance for business, as well as economic offenses in this regard. We presented certain data of importance for this issue in Serbia and the area of the Commercial Court in Valjevo. Our goal is to harmonize the work of the police and the judiciary in the area where the jurisdiction of the Commercial Court in Valjevo and Serbia extends, through the problems we have identified and pointed out. This is necessary in order to act more efficiently of all competent state bodies in this specific area of the fight against irresponsible legal entities and responsible persons in legal entities that organize work on the transport of goods within the scope of their activities.

\footnotetext{
KEY WORDS: criminal offenses / economic offenses / road safety / transport of cargo
} 